\title{
What does a map-skills-test tell us about Czech pupils?
}

\author{
MARTIN HANUS, MIROSLAV MARADA
}

Charles University in Prague, Faculty of Science, Department of Social Geography and Regional Development, Centre for Geographical Education, Prague, Czechia; e-mail: martin.hanus@natur. cuni.cz, miroslav.marada@natur.cuni.cz

ABSTRACT The paper focuses on the impacts of the general education curriculum reform that has placed the pupils' skills in the foreground of interest. Map skills are one of the most important groups of geographical skills. A test of map skills was drawn up in order to evaluate the level of map skills among pupils aged 11, 15 and 18. Its implementation proved, among others, the elementary assumption that map skills develop along with pupils' growing age. It was also proven that Czech pupils primarily master cognitively less demanding operations with maps such as location of objects in the map, while more difficult uses associated with map reading and analysis of information posed rather serious problems to them. Statistical figures showed that girls faced the problems significantly more often than boys. Last but not least, it was proven that pupils have not acquired map skills on such a level as prescribed by the curriculum for a given educational level.

KEY WORDS geographical education - map skills - test - curriculum - reform - Czechia

HANUS, M., MARADA, M. (2016): What does a map-skills-test tell us about Czech pupils? Geografie, 121, 2, 279-299.

Received September 2015, accepted January 2016.

(C) Česká geografická společnost, z. s., 2016 


\section{Introduction}

Maps are an information source all of us come across almost on a day-to-day basis, both when studying professional texts, in which maps depict the distribution of the examined phenomena and processes in space, and when watching routinely news from the world. As a result, it should be one of the tasks of geography not only to create various types of maps reflecting the distribution of geographical phenomena and processes in time and space, but also to teach the general public how to use maps, how to draw necessary information from them, how to correctly interpret the information and also what a critical approach should be assumed to the presented maps (both in terms of their content and form). In this, geographical education is, among others, at present indispensable. How has geographical education in Czechia managed to fulfil the objective? The answer is sought by this study describing the testing of map skills acquired by Czech pupils aged 11, 15 and 18 years.

The main goal of this study is to find out the degree of map skills acquisition by pupils at the end of key levels of education or, in other words, after the end of geographical education on a given level of the educational process, taking into account curricular requirements. In addiction the study intends to point out individual characteristics (e.g. age, sex, popularity of geography, etc.) that influenced pupils' results in the test.

To fulfil these goals map-skills-test, the main research tool, was constructed. It was addressed to observe map skills of three age groups of pupils - pupils at the age of 11,15 and 18. Pupils' results were subsequently analysed using the measures of average and statistical tests (e.g. Mann-Whitney U-test, Kruskal-Wallis test).

\section{Map skills}

In Czech geographical research, pupils' map skills have been a largely understudied topic. A different situation can be seen in foreign research in which map skills have been considerably examined, while the authoritative projects were conducted in the second half of the $20^{\text {th }}$ century (e.g. Rushdoony 1968; Stea, Blaut 1973; Sandford 1986; Stoltman 1992; Schee et al. 1994; Catling 1996; Brucker 2006; Wiegand 2006, etc.). Apparently, some of the studies are older than 30 years. It is obvious from this to what extent the focus of an educational system is influenced by pedagogic research. In the Czech educational system of the second half of the $20^{\text {th }}$ century, an emphasis was mainly laid on pupils' factographic knowledge, while the skills were largely ignored. On the other hand, the skills were preferred in Western European and North American countries in the second half of the $20^{\text {th }}$ century. Due to this, research projects examining the topic of skills can be found approximately 
20 years earlier than in the Czech environment (e.g. Knecht, Svatoňová 2008; Mrázková 2011; Hanus, Marada 2013). In it, the attention to particular skills only started to be paid after the curriculum reform that was carried out at the beginning of the new millennium. The reform was represented by the implementation of Framework Educational Programmes (FEP) outlining the content of education (for more information, see Rezníčková 2003b, 2009). The curriculum reform set as one of its main targets to change the teaching objectives, specifically a partial departure from pupils' factographic knowledge and preference of skills, in particular the skills of the work with information (i.e. primarily to find and process the information in order to solve a specific problem). The changes were expected to make pupils better prepared for life in the dynamically developing information society. One of the weaknesses of the curriculum reform is the fact that the documents (e.g. FEP) were often drawn up without continuity with the research projects examining the real state of knowledge and skills among Czech pupils. This is why the projects only started to be launched in reaction to the changes occurring in the school environment. This had an impact on the field of geography that more or less lacked research projects dealing with the level of Czech pupils' geographical skills. This state of affairs has only changed in recent years in which

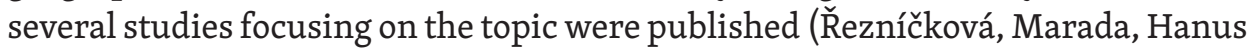
2014; Hanus, Marada 2013; Mrázková 2011; Knecht, Svatoňová 2008).

This study focuses on map skills whose delineation is primarily derived from a definition of skills on the general level. In the Czech environment, there is a general acceptation of the delineation by Švec (1998, p. 12) who defines skills as "a rather complex ability of the subject (that includes an internal model of skills fuelled by capabilities, experiences, learning style, motives and perceptions) to settle task and problem situations manifested by a perceptible activity". Based on Švec (1998) and ̌̌ezníčková (2003a) one can delineate map skills as (Hanus, Marada 2014) "a rather complex ability (fuelled by capabilities, experiences, learning style, motives, perceptions and partly also knowledge) to operate with the map".

If we focus on a specification of the group of map skills, we can use the conclusions of many studies devoted to the topic. Authors of the studies dealing with map skills mostly consider them a precondition for the work with map. Nevertheless, individual studies differ in the definition of what type of work with map is included in map skills.

E.g., in International Charter on Geographical Education (Haubrich 1994) map skills are described as a basis of geographical skills, with a stress on the ability to read, use and interpret maps. In a similar spirit, map skills are also specified by Wiegand (2006), van den Berg, van Dijk (1994) and van der Schee et al. (1994) who consider map skills the reading, analysis and interpretation of maps.

Brucker (2006) and Hütterman (2004) describe map skills as an ability to read, evaluate and interpret the content of maps as well as to compare, distinguish and 
use maps in certain situations. Unlike the above studies, they also mention the ability to draw simple maps, whereby the dimension of map creation is added.

What skills out of the rather variegated set of map skills can be denoted as core map skills? When trying to find the answer one can use the conclusions of the study by Hanus and Marada (2013), within whose framework an analysis of curricular documents of Czechia, Slovakia, the USA and Finland was conducted with the use of the Revised Bloom's Taxonomy of Educational Objectives.

It is apparent from the results of the analysis that one can denote as core map skills those falling into three categories of the Revised Bloom's Taxonomy:

- the category of remembering factual knowledge - to locate objects in a map

- applying procedural knowledge - to work with map as a source of information (primarily the ability to read a map and to gain from it required information)

- creating on the basis of procedural knowledge - to create maps and map-related depictions.

This structuration more or less confirms the delineation of map skills used in professional literature (see above). Based on these results, the map-skills test was constructed (see the text below), focusing on the categories remembering factual knowledge and applying procedural knowledge.

Using the above conclusions, one can denote (Hanus, Marada 2014) as map skills "a rather complex ability (fuelled by capabilities, experiences, learning style, motives, perceptions and knowledge) to do various activities with map, especially to read, analyse, interpret and create maps".

\section{Methodology}

With its subject, this study is a part of subject didactics, specifically the didactics of geography. As this study has set as its objective to examine the degree of acquisition of map skills among pupils of various age groups, for the sake of a better understanding of the test it is necessary to outline the basic characteristics relating to the evaluated sample and research tool (i.e. the test of map skills).

The dependence of the variables was evaluated on the basis of verification of validity of partial hypotheses relating to the influence of the above characteristics on the distribution of achievement in the test. The validity of these hypotheses was verified by means of statistical tools, specifically the Mann-Whitney U test and the Kruskal-Wallis test ${ }^{1}$. All null hypotheses ${ }^{2}$ were verified at the significance level of 0.05 .

1 Mann-Whitney U test and the Kruskal-Wallis test are a non-parametric tests. Mann-Whitney $\mathrm{U}$ test is used to compare two sample medians that come from the same population. It is used 


\subsection{Sample under observation}

The research wants to find out the degree of map skills acquisition by pupils at the end of individual levels of education or, in other words, after the end of geographical education on a given level of the educational process, taking into account curricular requirements. Following the research objectives, a group of tested pupils was specified. As a result, the testing of map skills targets the following three groups of pupils:

1. Pupils at the end of the primary schools. The category includes the pupils aged 10-12 years, with a clear dominance of 11-year-old pupils. To make the text more understandable and clear, this group of pupils will be denoted summarily as pupils at the age of 11 years, still bearing in mind the above age variability.

2. Pupils at the end of the lower secondary schools, i.e. those finishing their elementary education. The age of pupils in this middle category most often ranges from 14 to 16 years (exceptionally also 17), with an absolute dominance of 15 -year-old pupils. Hence the overall denotation of the group as pupils aged 15 years.

3. Pupils finishing their upper secondary education with a school-leaving examination; the group may include the pupils of the last (fourth) class of secondary schools, but also pupils of lower classes (the third in particular), who have already finished the compulsory teaching of geography (i.e. bindingly prescribed by official curricular documents). The category includes the pupils aged 17-20 years, with the biggest proportion being occupied by 18-year-old pupils. This is why in further text we will refer to it as the group of pupils aged 18 years.

The testing was conducted in academic year 2011/2012 on a sample of 1,323 pupils attending thirteen schools located in six regions of Czechia (Prague, Central Bohemia, Liberec, Pardubice, Moravian-Silesian and South Moravian).

When assessing the test sample from the viewpoint of type of school (see Figure 1 for the typology of schools in Czechia) and educational level, one can see

to test whether two medians are equal or not. It is mostly used for ordinal data. Kruskal-Wallis test assesses for significant differences on a continuous dependent variable by a grouping independent variable (with three or more groups). The most common use is in case of analysis based on one nominal variable (e.g. sex, age, school mark, etc.) and one measurement variable (e.g. success rate). Both tests are commonly used to verify null hypothesis which assumes that the median values of the samples are the same (for more information see e.g. McDonald 2014 or Chráska 2007).

2 Null hypotheses are often said to be that the medians of the groups are equal. In case of above mentioned tests the medians of two variables are compared: success rate (in separate tasks, sets of tasks and whole tests) and one of the following: sex, age, type of school, school mark, popularity of geography, etc. One of the verified null hypothesis was for example The distribution of "task 1 success rate" is the same across categories of "school mark". 


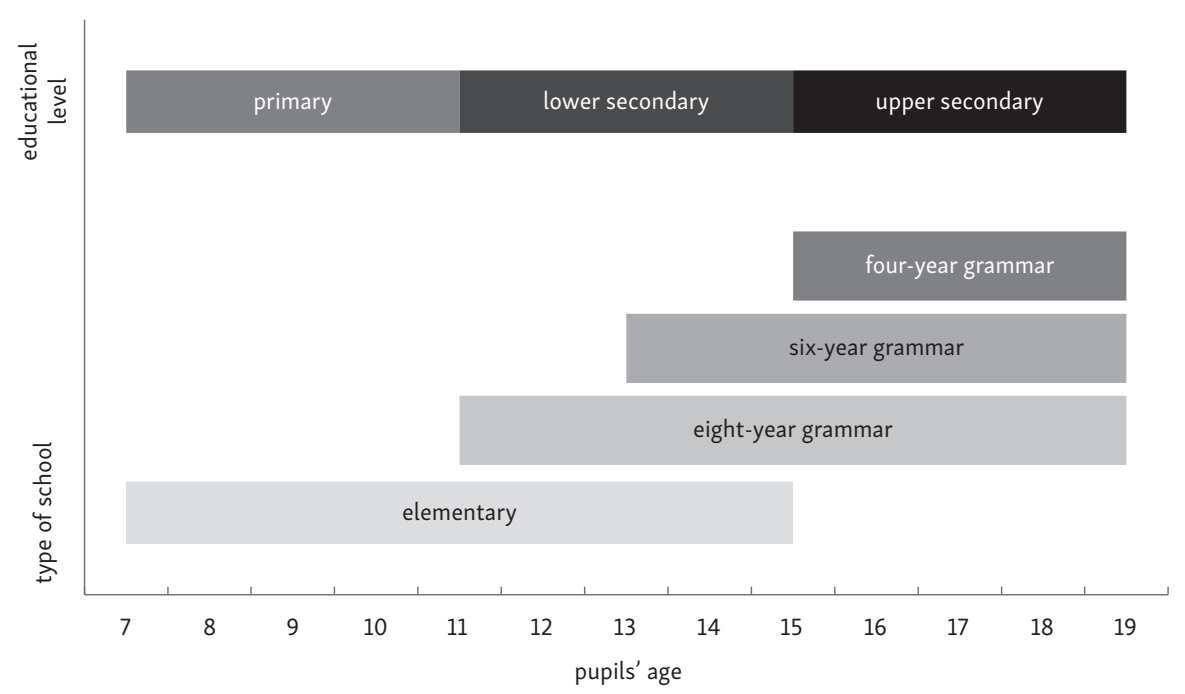

Fig. 1 - School typology in Czechia. Typology of Czech schools based on the prevailing age of pupils is depicted. Only types of school mentioned in the text of this article are included. Source: authors.

Tab. 1 - Structure of sample by age, sex and educational level

\begin{tabular}{llllllr}
\hline Age & Total & Share (\%) & Sex & Type of scholl & Educational level & Total \\
\hline 11 & 411 & 31.0 & $\begin{array}{l}52.1 \text { boys, } \\
\text { 47.9 girls }\end{array}$ & $\begin{array}{l}\text { elementary, } \\
\text { grammar }\end{array}$ & $\begin{array}{l}\text { end of primary, beginning } \\
\text { of lower secondary }\end{array}$ & 245 \\
\hline 15 & 509 & 38.5 & $\begin{array}{l}40.3 \text { boys, } \\
59.7 \text { girls }\end{array}$ & $\begin{array}{l}\text { elementary, } \\
\text { grammar }\end{array}$ & end of lower secondary & 166 \\
\hline 18 & \multirow{2}{*}{403} & \multirow{2}{*}{30.5} & $\begin{array}{l}34.5 \text { boys, } \\
\text { 65.5 girls }\end{array}$ & grammar & end of upper secondary & 412 \\
& & & & & 403 \\
\hline
\end{tabular}

Source: authors

Notes: Age denotation expresses predominant age of respondents in the group. In the Czech environment, one can come across four-year grammar schools, that are purely upper secondary schools providing education to the pupils aged 15 to 18 (19) years, and eight-year (sometimes six-year) gramar schools that educate the pupils since the age of 11 (13) years. They latter work selectively because they are attended by more gifted pupils who are judged by more difficult criteria. This is so despite the fact that on the official level, the lower classes of eight(six)-year grammar schools (for pupils aged 11/13-15 years) use the same binding curricular documents as the second level of elementary schools. Officially, the requirements for pupils of both types of school are identical, but the reality of school practice differs.

a clear preponderance of grammar schools (ca. $3 / 4$ of respondents as against $1 / 4$ of respondents from elementary schools). This state of affairs is mainly due to the rather unclear categorisation of eight-year grammar schools (for pupils ages 11-18). Based on the system of curricular documents and their requirements, the lower classes of these schools (classes 1-4) should be included in the category of elementary schools (by ending these classes, a pupil finishes compulsory 
elementary education), while the higher classes should be classified as upper secondary schools. However, in this categorisation one can encounter problems in the answers by respondents themselves as most pupils of the lower classes of eight-year grammar schools chose to reply that they attended an upper secondary school (see Table 1). Their choice is supported by the fact that they do not have to pass entrance exams when leaving lower classes and start attending upper classes of grammar school.

Although this seems to be rather complicated and problematic, it makes no essential problems in context of results analysis. It is due to the following facts. Firstly, in terms of binding curricula lower classes of grammar schools (attended by pupils aged 11 to 15 ) are equivalent to elementary school classes. It means that expected outcomes required from pupils of these two school types are similar. Secondly, the total (for the sample as a whole) analysis of success rate in terms of school type was not made. Due to the considerable age diversity of the sample this analysis seemed to be meaningless. Consequently, the "type of school" variable was used for further specification of success rate analysis only within group aged 11 and group aged 15.

The respondents' structure by sex reveals a numerical superiority of girls (56\%) over boys ( $41 \%)$, while less than $3 \%$ of respondents did not give the required data. This state of affairs is largely influenced by the structure of the category of 18-year pupils with evident, considerable differences in the number of tested girls and boys $^{3}$.

\subsection{Map-skills-test}

Based on the formulation of the testing purpose and delineation of the groups of tested pupils, the basic concept of the test was set down. It was decided that it will be conceived as a test of increasing difficulty, i.e. that it will contain the tasks verifying the map skills of pupils of all three levels of education and they will be arranged according to their difficulty. When drawing up the test of increasing

3 According to the statistics of the Office for Information in Education (http://www.uiv.cz), there were some 530,000 pupils in the school year 2010/2011, while girls accounted for $49.3 \%$ of them. Nevertheless, while boys constitute a majority of vocational schools pupils (53.8\%), girls are predominant among students of grammar schools (58.2\%). Some significant differences in the proportion of boys and girls were recorded among the 18-years old students of grammar schools - girls accounted for $61.2 \%$. This value more or less corresponds with girls' proportion within the framework of the group of 18 -year pupils who joined the testing. So, it could be stated that the proportion of boys and girls in the sample generally corresponds with the values of the proportion within the total population of Czech schools pupils. 
difficulty, there was the basic assumption that a pupil with map skills on a certain level will be always only able to solve the tasks of the relevant level(s) according to curricular requirements.

These conditions were considered when setting the deadline for the writing of the test. Forty minutes were given to solve it. This deadline was set down bearing in mind that for younger pupils, it is much more difficult to solve the tasks than for older ones. On the other hand, older pupils can in the ideal case very easily and fast solve the tasks testing the acquisition of requirements for lower educational levels.

As a result, only a single 21-task test is drawn up for all the tested groups of pupils. Seven tasks were reserved for the requirements that were to evaluate the pupils' map skills at each of the educational levels. The individual tasks then examined the requirements of map skills on 11-year pupils (tasks 1-7), 15-year pupils (tasks 8-14) and 18-year pupils (tasks 15-21). The increasing difficulty of the test is ensured by the emphasis on the evaluation of skills demanded by binding curricular documents at individual educational levels. When selecting specific curricular requirements whose achievement is tested by individual tasks, the primary use was made of Czech curricular documents and if there was a need, of the requirements of National Geography Standards of the USA (Bednarz et al. 1994). The requirements from the US curricula were mostly applied when formulating the tasks for 11-year pupils due to the low number of requirements regarding the pupils of this age group in the Czech curricula.

As far as the content and focus of individual test tasks are concerned, the conclusions of an analysis of curricular documents of Czechia, Slovakia, Finland and the USA (Hanus 2012; Hanus, Marada 2013) were used. It ensues from the analysis that the core of map skills within the categories of the Revised Bloom's Taxonomy of Educational Objectives is largely found in the following spheres: to remember factual knowledge, to apply procedural knowledge and to create procedural knowledge. During the testing, it was concentrated on the requirements on map skills from first two spheres. For examples of the test tasks see Box 1.

In all parts of the test, there is a predominance of the tasks verifying the ability to apply procedural knowledge, which clearly arises from the very substance of map skills. In the parts of the test verifying the skills of 11-year and 15-year pupils, there are also tasks verifying the knowledge of facts (which means less complex skills), while the part for 18-year pupils only contains the tasks focusing on the ability to apply procedural knowledge (Tab. 2).

Based on the above assumptions, the requirements relating to map skills of pupils from individual levels of elementary schools were identified. For obvious reasons, the curricular requirements are formulated in a general form. The tasks in the test verifying the individual requirements are one of the possible alternatives when specifying the requirement. Of the tasks, a test of map skills was drawn up that was submitted to a preliminary test in order to gain some awareness of its 


\section{Remembering factual knowledge, 15-years-old pupils}

\section{TASK}

Locate below mentioned Czech regions in the map.

\begin{tabular}{|l|}
\hline 1 - Prague \\
2 - South Bohemian region \\
3 - Karlovy Vary region \\
4 - Liberec region \\
5 - Moravian-Silesian region \\
6 - Pardubice region \\
7 - Zlín region \\
\hline
\end{tabular}

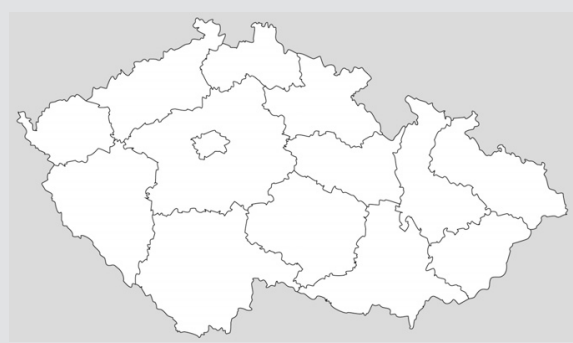

\section{Applying procedural knowledge, 11-years-old pupils}

\section{TASK}

Identify the correct place (A, B, C, D) in the map above which the aerial photo was taken.
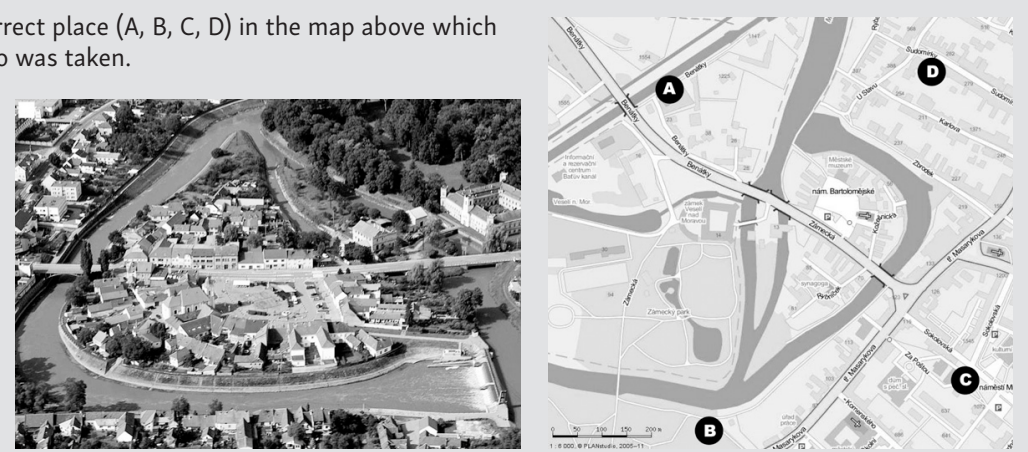

\section{Applying procedural knowledge, 18-years-old pupils}

\section{TASK}

Using the map, identify the correct landscape park described in the text.

Landscape park description:

- Landscape park does not lies in the neighbourhood of any national park.

- A river (depicted in the map) which source lies out of the park area flows through the center of the park. This river does not pass any other landscape park.

- The park is not declared as a biosphere reserve of UNESCO.

- Both the national nature reserve, both the national nature monument lies in the park area.

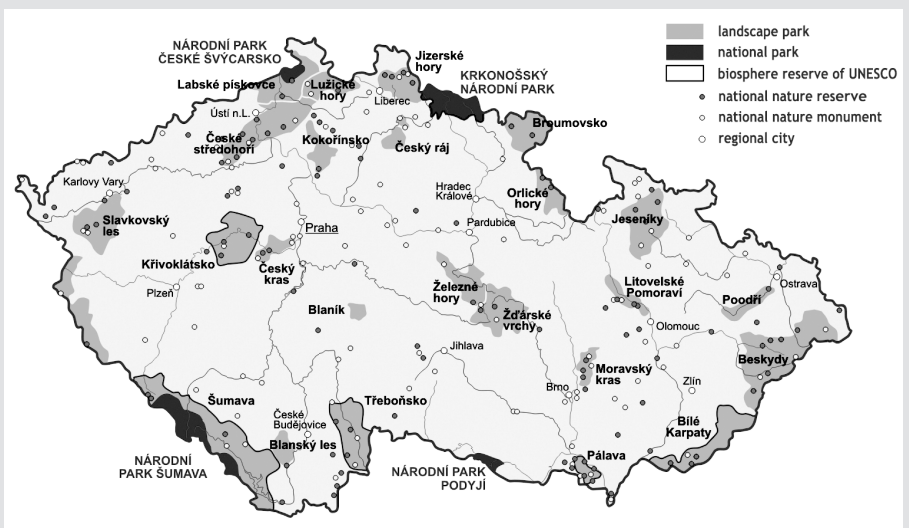

Box 1 - Examples of the test tasks 
Tab. 2 - Specification table of map-skills-test

\begin{tabular}{llcc}
\hline Part of test & Educational level & Number of tasks testing the knowledge \\
\cline { 3 - 4 } & & $\begin{array}{c}\text { Remembering factual } \\
\text { knowledge }\end{array}$ & $\begin{array}{c}\text { Applying procedural } \\
\text { knowledge }\end{array}$ \\
\hline Tasks 1-7 & primary & 1 & 6 \\
Tasks $8-14$ & lower secondary & 3 & 4 \\
Tasks 15-21 & upper secondary school & 0 & 7 \\
\hline
\end{tabular}

Source: authors

Note: FEP - Framework Education Programme; NGS - National Geographical Standards (Geography for Life)

basic qualities. Based on the preliminary test it was stated that the test is valid and, among others, has a rather high value of reliability (Cronbach's alpha 0.905).

\section{Results}

The testing included 1,323 pupils. Using the results of the testing, one can infer the following conclusions regarding Czech pupils' map skills.

As it is apparent from figures (see Figure 2) depicting the distribution of the success rate relating to the pupils of varying age within the whole test as well as its individual parts for individual age categories, pupils' map skills develop along with age, i.e. depending on their intellectual maturity and the level of education. This was proven by a higher achievement of pupils of higher age both in the whole test and its individual parts. The distribution of pupils' achievement tended to copy the normal distribution when it comes to the tasks for pupils of a given age.

The argument can be documented by a comparison of figures of average success rate of pupils of individual age groups within the framework of the whole test. The distribution of success rate in all age categories more or less corresponds with normal distribution. Nevertheless, while in the case of 11-year pupils the normal distribution is inclined to the left (towards the lower values of average achievement), in that of 18 -year pupils it is inclined to the right, towards higher rates of achievement. A comparison of above figures confirms, among others, the whole concept of the test with its increasing difficulty. If we place the Gaussian curve on the individual figures of success rate, then (if we proceed along the succession of individual parts in the test, from easier to more difficult tasks) one can observe a shift of the peak of the curve towards lower values of achievement in all age categories.

Within the distribution of pupils' achievement in the tasks corresponding with their age category, one can identify the same distribution both among the 


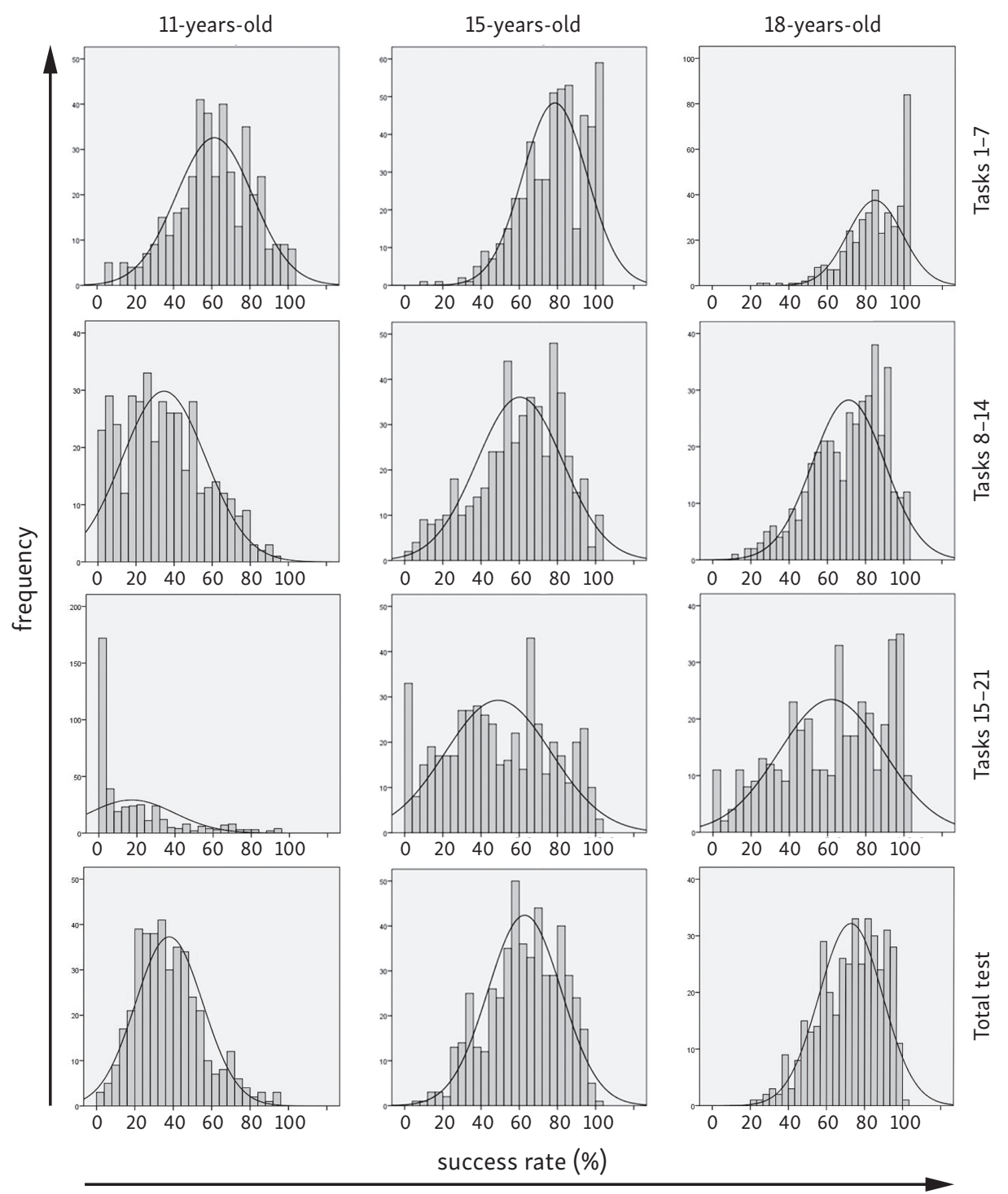

Fig. 2 - Distribution of pupils' success rate in the test. The maximal possible value of success rate is $100 \%$. Higher values of $x$ axis are depicted to maintain the symmetry of the normal distribution curve. Source: authors.

11-year old (within the framework of the tasks 1-7) and 15-year pupils (with the framework of the tasks 8-14). In this case, one can see a normal distribution with the peak of the Gaussian rate at around the $60 \%$ value of success rate, while most pupils achieved the success rate between 50 and $90 \%$. The peak of the Gaussian 
curve at around the value of $60 \%$ was also recorded in the case of 18 -year-old pupils within the framework of the tasks 15-21. However, the distribution according to the success rate differs from the previous categories. Unlike the normal distribution, it displays more peaks. This can be explained by the tasks' focus on the verification of requirements from the school-leaving examinations catalogue and also by a certain specialisation of the pupils before the school-leaving examination only on certain subjects, depending on the choice of the university or their future professional career.

When looking at the distribution of 11-year pupils' success rate, one can also identify relatively high values of achievement within the tasks 8-14, which are those verifying the requirements on the performance of 15 -year pupils. This can be considered the confirmation of the assumption (Hanus, Marada 2013) that the requirements on 11-year pupils' map skills are considerably underestimated in Czech curricular documents as pupils of this age are able not only to locate objects in maps, but also to master the skills of application nature, and to some extent even on a higher level of difficulty than demanded from them.

On the contrary, although the requirements on skills of the pupils aged 15 years were not identified as overestimated, a relatively high number of them only scored rather low values of success rate within the framework of the tasks 8-15. The fact is even more accentuated if we add to the set of requirements for 15-year pupils also those for 11-year-old ones that the older pupils ought to have already acquired. It is rather alarming that quite a high number of 15 -year pupils solved the tasks for younger pupils with a success rate of below $60 \%$.

On the other hand, 15-year pupils scored relatively good results in the tasks specified for 18-year pupils. Their achievement within these tasks was higher than that of 11-year pupils within the framework of the tasks 8-14. This can be attributed to the spiral arrangement of subject matter in the Czech curriculum within which upper secondary school students deepen (or repeat) the knowledge and skills they gained on the lower secondary school.

Eighteen-year pupils scored relatively high values of achievement in both parts of the test for younger pupils. However, in this category, too, there was a part of respondents who solved the tasks for the first level of elementary school with the success rate below $50 \%$. On the other hand, most pupils scored the success rate of over $90 \%$. High values of achievement were also recorded in the tasks verifying the requirements for 15-year pupils. Nevertheless, when taking a closer look at the results of individual tasks, one can see that 18-year pupils scored the success rate of $78.0 \%$ within the tasks verifying the requirements contained in the FEP EE (Framework Educational Programme for Elementary Education). The value can be considered relatively low because the mastering of these skills is already compulsory at the age of 15 years. Besides, the spiral arrangement of the subject matter is supposed to fix and deepen these skills. One can state that that there was 
Tab. 3 - Success rate based on the curriculum requirements

\begin{tabular}{lcccc}
\hline Curriculum & Pupils' age & \multicolumn{3}{c}{ Success rate (\%) } \\
\cline { 3 - 5 } & & tasks 1-7 & tasks 8-14 & tasks 15-21 \\
\hline FEP & 11 & 74.2 & 41.1 & 17.3 \\
& 15 & 86.6 & 67.5 & 49.4 \\
& 18 & 93.2 & 78.0 & 62.4 \\
\hline NGS & 11 & 59.5 & 18.8 & 20.6 \\
& 15 & 77.9 & 42.6 & 53.4 \\
& 18 & 83.5 & 54.1 & 67.5 \\
\hline
\end{tabular}

Source: authors

Note: FEP - Framework Education Programme; NGS - National Geographical Standards (Geography for Life)

a certain fixation and deepening of the skills within the framework of secondary schools study as the value for 15 -year pupils reached $67.5 \%$. However, here, too, the value must be seen as a certain warning because the acquisition of these skills is compulsory and instead of the ideally expected $100 \%$ success rate, the pupils only reached a two-third success rate. This warning also gains importance along with the fact that in Czechia, grammar schools are attended primarily by talented students interested in subsequent university studies.

Unlike the tasks focusing on the testing of requirements from FEP, those verifying the requirements from National Geography Standards were solved with a lower success rate by the pupils of all age categories, which can be attributed to the fact that the skills are not being sufficiently trained in the teaching process at our schools (see Table 3).

The goals and curricular requirements from which individual tasks ensue can also be used for a more detailed look at the pupils' map skills. Based on the goals, one can identify six partial groups of map skills within the test. The following skills were verified in it:

(a) Transfer between two different depictions of reality

(b) Location of objects

(c) Orientation in the map

(d) Drawing in the map

(e) Gaining of information from the map

(f) Work with the map scale.

In all age categories, there was the same distribution of achievement within the framework of these groups of skills. Pupils of all age groups solved with an above-average achievement in particular the tasks verifying orientation in the map as well as location of objects. On the opposite side of the scale with a low average achievement, there are the skills with the map scale, gaining of information from the map and transfer of information between two various depictions of reality. 


\subsection{Factors influencing pupils' results}

An evaluation of tested pupils' map skills as a whole is not the goal of this study because this can be called rather questionable. This is mainly due to the fact that the tested sample is not homogeneous, considerably varying in age and educational level and, as a result, also by the degree of acquired map skills. On account of this, it is not suitable to include the results of pupils' individual groups in a single, overall evaluation in which the results would be described mainly by their mean values, whereby their informative value would be very low. On the contrary, within the framework of the whole sample of tested pupils one can significantly verify the dependence of achievement in the test (individual tasks) on other variables such as the mark, popularity of geography, sex and the town in which a school is situated.

The evaluation of the rightfulness of the hypotheses by the above tests makes it clear that the pupils' results in the whole test as well as its individual parts are influenced both by the age and the mark on the school report and the popularity ${ }^{4}$ of geography. The respondents' sex also has a relatively strong influence on the achievement. In general, boys score better results, both in the whole test and its individual parts.

If we focus more on the above dependence between sex and achievement in individual tasks, it is apparent that significant differences in the boys' and girls' achievement were recorded in 11 tasks. The distribution of these tasks in the test is relatively even: four tasks are found in the first part of the test, another four in its second part and three in the last part. It is obvious from the individual evaluation of these tasks that the influence of sex on achievement was not proven for the tasks verifying factual knowledge, but only in the case of skills (i.e. procedural knowledge). Boys scored a significantly higher success rate in both tasks focusing on the work with the map scale and in that verifying the perception of space and mutual distribution of objects in it. Among older pupils, one should also add the tasks demanding both inductive and deductive approach to the solution. From the viewpoint of difficulty of individual tasks, the biggest differences between boys' and girls' achievement were revealed in those with a medium level of difficulty and in difficult tasks. Very difficult tasks (irrespective of sex, most pupils guessed randomly some solution or did not try to solve them at all) and easy as well as very easy tasks (most pupils solve them successfully irrespective of sex) revealed few, if any differences between boys' and girls' achievement. Nevertheless, with some rare exceptions, boys of all age categories scored higher success rates in all tasks than the girls of the same age.

4 The popularity of geography was detected using the statement at the beginning of the test. Pupils should choose one of the answers: I like geography $\times$ I don't like geography $\times$ I am quite not sure. 

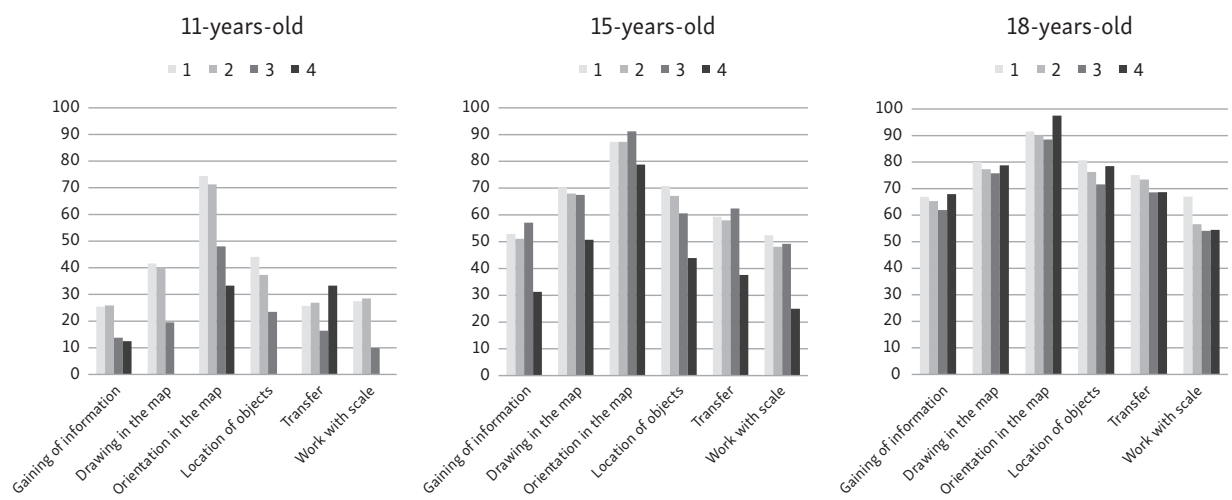

Fig. 3 - Pupils' success rate (\%) distribution based on their school report mark. Mark 5 (insufficient) was not recorded in the sample. Source: authors.

The dependence of the mark on the achievement of the pupils' total sample proved significant both within the whole test and its individual parts. If we compare the pupils' achievement in the above mentioned six groups of map skills with the marks on their latest school reports, it is quite obvious (see Figure 3 ) that the mark most corresponds with the success rate within the tasks verifying the location of objects (only 18-year pupils with a 4 on their school report scored a higher success rates than pupils of the same age whose achievement in the latest school report was evaluated with a 3$)^{5}$. This suggests the assumption that in the practical teaching at school, the pupils' evaluation is often based on knowledge and ability to remember. However, one has to state on behalf of the teachers that since curricular documents still lay a rather big emphasis on remembering factual knowledge (location of objects in the map in particular), the teachers must place it in the teaching process and then evaluate the level of its acquisition. On the other hand, the pupils' achievement in the tasks verifying the ability to read information from the map is only very loosely connected with their marks. In these tasks, e.g. 15 -year pupils with a 3 on their school reports scored a higher success rate than those who obtained 1, just as 18-year pupils with a 4 on their school reports solved the tasks better than pupils of the same age with 1 .

Within the framework of the whole evaluation of all tested pupils' results, one could also prove a remarkable influence of popularity of the subject on pupils' achievement. The influence of popularity of the subject on the pupils' achievement was mostly apparent in knowledge tasks and among older pupils also in the tasks demanding both inductive and deductive solution. As far as the oldest pupils are

5 Czech schools mostly use a five-degree scale to evaluate pupils. Mark 1 corresponds with "excellent" and mark 5 with "insufficient". 
concerned, popularity proved to be an important factor influencing achievement, but the tasks that were influenced by the popularity are so much varied that it was impossible to distinguish any general trend. This state of affairs among 18-year pupils that is also supported by younger pupils' results can be explained by the pupils' differing motivation. Just this motivation is largely caused by the popularity of a subject. This can be the motivation:

- For learning that brings about better results in knowledge tasks.

- Towards acquisition of other skills (such as new methods of solution to problems), which can have an impact on the tasks demanding both inductive and deductive solution.

- Towards achieving good results, which mainly played a role among older pupils who were more motivated to score better results in the test, although they knew that its results will not be included in the overall evaluation of their performance in the geography.

The pupils' achievement was very strongly influenced by the type of school they attend, i.e. whether it is an eight-year grammar school or an elementary school (at the lower secondary level). One can state that virtually all grammar school students scored a higher success rate in all tasks, in both age categories. The most significant differences in the achievement were seen in the tasks verifying the map scale skills and also in the tasks for older pupils. On the other hand, small differences were recorded in easy and very easy tasks that were solved successfully by almost all pupils, irrespective of the type of school they attend. In the results, one could discern considerable differences in the achievement of pupils of elementary schools and students of grammar schools. However, there is still the question of whether this is a desirable state of affairs because both type of schools must meet the same curricular documents. It is obvious from this that within the framework of verification of FEP for Elementary Education (primary level) requirements the pupils of both groups should reach similar achievements whose success rate should approach $100 \%$.

\section{Conclusions}

Taking into account the above results, one can state that Czech pupils' map skills develop along with age, both in the quantitative and, primarily, qualitative respects. Minor (but still significant) differences were discerned in the degree of acquisition of map skills among 15-year and 18-year pupils, which can be attributed to the spiral arrangement of the subject matter at Czech schools. Due to this, our recommendations unequivocally call for the abandonment of spiral arrangement within the framework of development of map skills and for a differentiation of 
map skills requirements of both age groups, both on the quantitative and, above all, qualitative levels. For this purpose, it is advisable to lay an increased emphasis on more complex map skills, while the development of skills associated with independent creation of map outputs is of major importance among pupils of this age.

The results of the research have also confirmed the assumption that pupils tend to master less complex cognitive map skills such as location of topographic names while more complex skills such as synthesis of information from various maps and reading from a rarely frequented map type posed serious problems to them. This can be, among others, attributed to the surviving factographic focus of the teaching process at Czech schools. This state of affairs can be changed by the support to the inclusion of the development of complex map skills in the teaching process as well as the level of project curriculum. This should happen by giving up the stress on the requirements on less complex map skills (anyway, they are already part of more complex skills) for older pupils in FEP and especially by drawing up the requirements of geographical education for all three educational levels that would specify the requirements from FEP and reflect the above recommendations.

If we only focus on verifying the map skills bindingly prescribed in FEP, ideally all pupils are to solve the tasks determined for their age category with the $100 \%$ success rate, which would not correspond with the normal distribution. Nevertheless, testing results have shown that present-day pupils are far from reaching this required achievement. One can infer from this that in school practice, the requirements prescribed by FEP are not viewed as a minimum basis that should be acquired by all pupils, including the worst ones, but, rather, as a description of what an average pupil of a given age should master. This can refute the assumption that the requirements for pupils' achievement in binding curricular documents are suitable formulated and are realistically reflected in the teaching process, which would presume the acquisition of required map skills by all pupils of a given age.

One can see another problem: the girls' lower success rate in the test, which is a sign of a lower level of map skills. Similar conclusions were also arrived at by other studies examining the map skills of boys and girls (e.g. Dabbs et al. 1998). Hence the recommendation that in the teaching process teachers should devote a bigger effort to the development of map skills of girls (naturally also of the boys with map skills on a lower level) so that all pupils reach such a level of map skills that is required in binding curricular documents.

Last but not least, one has to point to the alarming conclusions with regard to the evaluation of the skills right in the school practice. Although it is difficult to arrive at generalisations on the basis of the research described in this study, the results have suggested that the degree of acquisition of map skills does not correlate with the pupils' overall evaluation in geography. This is stated even with the awareness of the fact that the pupils' overall evaluation is influenced by many 
other factors ignored by the test. As a result, one can presume that despite the curriculum reform, teachers mainly emphasize the evaluation of the pupils' factual knowledge. However, the argument is yet to be proven by a subsequent detailed research with a focus on the way skills are evaluated in the teaching process at Czech schools.

\section{References}

BEDNARZ, S.W. et al. (1994): Geography for Life. National Geographic Society, Washington.

BRUCKER, A. (2006): Karten. In: Haubrich, H. (ed.): Geographie unterrichten lernen. Die neue Didaktik der Geographie Konkret. Oldenbourg, München, 196-199.

CATLING, S.J. (1996): Technical Interest in Curriculum Development: A Programme of Map Skills. In: Williams, M. (ed.): Understanding Geographical and Environmental Education. The Role of Research. Continuum International Publishing, London, 93-111.

DABBS, J.M., CHANG, E., STRONG, R.A., MILUN, R. (1998): Spatial Ability, Navigation Strategy, and Geographic Knowledge Among Men and Women. Evolution and Human Behavior, 19, 2, 89-98.

HANUS, M. (2012): Czech pupils' map skills: pupils of various age comparison. Doctoral thesis, Charles University in Prague, Dpt. of Social Geography and Regional Development, Prague.

HANUS, M., MARADA, M. (2013): Mapové dovednosti v českých a zahraničních kurikulárních dokumentech: srovnávací studie. Geografie, 118, 2, 158-178.

HANUS, M., MARADA, M. (2014): Mapové dovednosti: vymezení a výzkum. Geografie, 119, 4, 406-422.

HAUBRICH, H. (1994): International Charter on Geographical Education. Hochschulverband für Geographie und ihre Didaktik. Nürnberg.

HÜTTERMANN, A. (2004): Karte und Atlas, In: Schallhorn, E. (ed.): Erdkunde-Didaktik. Praxishandbuch für die Sekundarstufe I und II, Cornelsen, Berlin, 199-205.

CHRÁSKA, M. (2007): Metody pedagogického výzkumu: základy kvantitativního výzkumu, Grada, Praha.

VÚP (2007): Framework Educational Programme for Elementary Education, VÚP, Praha.

KNECHT, P., SVATOŇOVÁ, H. (2008): Developing Educational Cartography: Pupils' Criteria for Selecting a School Atlas. In: Donert, K., Wall, G. Future (eds.): Prospects in Geography. Liverpool University Press, Liverpool, 325-333.

McDONALD, J.H. (2014): Handbook of Biological Statistics ( $3^{\text {rd }}$ ed.). Sparky House Publishing, Baltimore, Maryland.

MRÁZKOVÁ, K. (2011): Kartografické dovednosti ve výuce zeměpisu: teoretický model a výsledky výzkumného šetření. In: Janík, T., Najvar, P., Kubiatko, M. (eds.): Kvalita kurikula a výuky: výzkumné př́stupy a nástroje. MUNI Press, Brno, 193-205.

RUSHDOONY, H.A. (1968): A child's ability to read maps: summary of research. Journal of Geography, 67, 213-222.

ŘEZNíČKOVÁ, D. (2003a): Geografické dovednosti, jejich specifikace a kategorizace. Geografie, 108, 2, 146-163.

ŘEZNÍČKOVÁ, D. (2003b): Geographical Education in the Czech Republic - the past, present and future. International Research in Geographic Education, 12, 2, 148-154.

ŘEZNíČKOVÁ, D. (2009): The transformation of geography education in Czechia. Geografie, $114,4,316-331$. 
ŘEZNÍČKOVÁ, D., MARADA, M. HANUS, M. (2014): Geographic skills in Czech curricula: analysis of teachers' opinions. In: Schmeinck, D., Lidstone, J. (eds.): Standards and Research in Geography Education - Current Trends and International Issues , Mensch Buch Verlag, Berlin, 35-47.

SANDFORD, H.A. (1986): Atlases and Mapwork. In: Boardman, D. (ed.): Handbook for Geography teachers. The Geographical Association, Sheffield.

STEA, D., BLAUT, J. (1973): Some preliminary observations on spatial learning in school children. In: Downs, R.M., Stea, D. (eds.): Image and Environment, IL: Aldine, Chicago.

STOLTMAN, J. (1992): Teaching Map and Globe Skills, K-6, Rand McNally, Skokie.

ŠVEC, V. (1998): Klíčové dovednosti ve vyučování a výcviku. MU, Brno.

VAN DEN BERG, G., VAN DIJK, H. (1994): The development of map skills. In: Brinkman F.G., Schee, J.A. van der, Schouten van Parreren, M.C. (eds): Curriculum research: different disciplines and common goals. Vrije Universiteit, Amsterdam, 193-199.

VAN DER SCHEE, J.A., ZIJPP VAN DER, T. HOEKVELD-MEIJER, G. (1994): Maps skills and geography teaching. In: Brinkman F.G., Schee van der, J.A., Schouten van Parreren, M.C. (eds.): Curriculum research: different disciplines and common goals. Vrije Universiteit, Amsterdam, 169-191.

WIEGAND, P. (2006): Learning and Teaching with Maps. Routledge, Abingdon.

\section{SHRNUTÍ}

\section{Co vypovídá test mapových dovedností o českých žácích?}

Kurikulární reforma, která proběhla v Česku počátkem tisíciletí, postavila žákovské dovednosti do popředí zájmu, tedy i do popředí zájmu geografického vzdělávání. Jednou ze skupin dovedností, které lze považovat za specificky geografické - jsou tedy rozvíjeny především v rámci výuky geografie, jsou dovednosti práce s mapou - mapové dovednosti. Mapa je jedním ze zdrojů informací, s nimiž se každý z nás téměř každodenně setkává, a to jak při studiu odborných textů, v nichž mapy dokládají rozložení studovaných jevů či procesů v prostoru, tak i při běžném sledování zpravodajství ze světa. Jedním z úkolů geografie by proto mělo být nejen vytvářet různé druhy map dokládajících rozložení geografických jevů a procesů v prostoru a v čase, ale také naučit širokou veřejnost s těmito mapami pracovat, vyčíst $\mathrm{z}$ nich potřebné informace, tyto informace správně interpretovat a také na předkládané mapy kriticky nahlížet (a to jak po stránce obsahové, tak také formální). V tomto je, mimo jiné, geografické vzdělávání v současnosti nezastupitelné. Jak se daří tento cíl naplňovat geografickému vzdělávání v Česku? Odpověd' hledá tato studie popisující ověřování mapových dovedností českých žáků různého věku.

Cílem výzkumu je zjistit míru osvojení mapových dovedností žáků na konci jednotlivých stupňů vzdělávání, respektive po ukončení výuky geografie na daném stupni vzdělávání, a to s ohledem na kurikulární požadavky. V návaznosti na cíle výzkumu bylo testování zaměřeno na tři skupiny žáků, a sice:

1. Na žáky na konci prvního stupně základních škol. V této kategorii se vyskytují žáci ve věku 10-12 let, přičemž jasně dominují žáci jedenáctiletí.

2. Na žáky na konci druhého stupně základních škol, resp. ukončující základní vzdělávání. Věk žáků v této střední kategorii se pohybuje nejčastěji mezi 14-16 lety (výjimečně i 17), přičemž naprosto dominantní jsou žáci patnáctiletí. 
3. Na žáky ukončující středoškolské vzdělání s maturitou; do této skupiny je možné zařadit žáky posledních ročníků středních škol, ale také žáky nižších ročníků (zejména 3. ročníků), kteří však již ukončili povinnou (tj. oficiálními kurikulárními dokumenty závazně předepsanou) výuku geografie na škole. V kategorii se vyskytují žáci ve věku 17-20 let, přičemž nejvyšší podíl zaujímají osmnáctiletí žáci, z toho důvodu s nimi budeme nadále operovat, jako se skupinou žáků ve věku 18 let.

Za účelem naplnění cíle studie byl sestaven test mapových dovedností. Ten byl připraven jako test gradující náročnosti, který obsahuje úlohy ověřující mapové dovednosti žáků všech tří stupňů vzdělávání, přičemž ty jsou uspořádány na základě obtížnosti. Základním předpokladem při sestavování testu gradující náročnosti bylo, že žák s mapovými dovednostmi na určité úrovni bude schopen úspěšně řešit vždy jen úlohy odpovídající úrovně (dle kurikulárních požadavků). To znamená, že jedenáctiletí žáci v ideálním případě správně vyřeší úlohy $1-7 \mathrm{~s}$ tím, že schopnější žáci dokážou vyřešit i některé z úloh 8-14. Patnáctiletí žáci pak ideálně všichni vyřeší úlohy 1-14 a ti zdatnější také některé z úloh 15-21, osmnáctiletí žáci by již měli být schopni vyřešit všech 21 úloh, tj. celý test.

Na základě výsledků testování, kterého se zúčastnilo 1323 respondentů, je možné konstatovat, že mapové dovednosti žáků se vyvíjejí s věkem, a to jak po stránce kvantitativní, tak především po stránce kvalitativní. Menší rozdíly (i když přesto signifikantní) se prokázaly v míře osvojení mapových dovedností mezi 15letými a 18letými žáky, což je přičítáno spirálovitému uspořádání učiva na českých školách. V rámci rozložení úspěšnosti žáků v úlohách odpovídajících jejich věkové kategorii lze identifikovat stejné rozložení u jedenáctiletých (v rámci úloh 1-7) i u patnáctiletých (v rámci úloh 8-14) žáků. V tomto případě se jedná o normální rozdělení s vrcholem Gaussovy křivky okolo hodnoty úspěšnosti $60 \%$, přičemž nejvíce žáků dosáhlo úspěšnosti v rozmezí 50-90\%.

Výsledky výzkumu také potvrdily předpoklad, že žáci ovládají spíše méně kognitivně náročné dovednosti práce s mapou, jako např. lokalizace místopisných názvů, naopak komplexnější dovednosti jako syntéza informací z různých map, čtení z map málo frekventovaného typu již činily žákům výraznější obtíže. To lze mimo jiné přičíst stále přetrvávajícímu faktografickému zaměření výuky na českých školách.

Na základě podrobných analýz využívajících neparametické testy bylo identifikováno, že úspěšnost žáků v testu je ovlivněna jak věkem, tak také známkou na vysvědčení a oblibou geografie. Relativně silný vliv na úspěšnost úloh má také pohlaví respondentů. V celkovém souhrnu dosahují chlapci lepších výsledků, a to jak v celém testu, tak i v jeho jednotlivých částech. Pokud bychom se více zaměřili na uvedenou závislost pohlaví a úspěšnosti v jednotlivých úlohách, pak je zřejmé, že signifikantní rozdíly v úspěšnosti chlapců a dívek byly zaznamenány u 11 úloh (z celkových 21). Dívky se dokázaly chlapcům vyrovnat zejména ve znalostních úlohách, zatímco v úlohách vyžadujících aplikaci dovedností, jako je práce s měřítkem, orientace v prostoru či převod informací z jednoho zobrazení do jiného byli chlapci výrazně úspěšnější. Nejinak tomu bylo u i úloh vyžadujících induktivně-deduktivní způsob řešení.

Pokud bychom se zaměřili pouze na ověřování mapových dovedností závazně předepsaných v RVP, pak by v ideálním případě měli všichni žáci řešit úlohy určené jejich věkové kategorii s úspěšností 100 \%, což by již normálnímu rozdělení neodpovídalo. Nicméně výsledky testování ukázaly, že současní žáci ani zdaleka nedosahují této požadované úspěšnosti. Z toho lze usoudit, že požadavky uvedené v RVP nejsou ve školní praxi vnímány jako minimální základ, který by si měli osvojit všichni, tj. i ti nejslabší, žáci, ale spíše jako popis toho, co by si měl osvojit průměrně zdatný žák daného věku. 
V neposlední řadě se jako alarmující jeví závěry ohledně hodnocení dovedností př́ímo ve školní praxi. Ačkoliv je na základě výzkumu popsaného v této studii obtížné dojít ke zobecňujícím tvrzením, tak výsledky poukazují na to, že míra osvojení (mapových) dovedností nekoreluje s celkovým hodnocením žáků v geografii. A to i s vědomím toho, že celkové hodnocení žáků je ovlivněno mnoha dalšími faktory nezjištovanými testem. Lze tedy předjímat, že navzdory kurikulární reformě jsou vyučujícími hodnoceny především faktické znalosti žáků. Avšak toto tvrzení je třeba doložit následným detailním výzkumem zaměřeným za způsob hodnocení dovedností ve výuce na českých školách.

Obr. 1 Typologie škol v Česku. Je to zobrazena typologie českých škol na základě převládajícího věku žáků. Zahrnuty jsou jenom typy škol, o nichž je zmínka v textu tohoto článku.

Obr. 2 Rozložení úspěšnosti žáků v testu. Maximální možná míra úspěšnosti je 100 \%. Vyšší hodnoty na ose x jsou uvedeny, aby se udržela symetrie křivky normálního rozložení.

Obr. 3 Rozložení míry úspěšnosti žáků dle známky na vysvědčení. Pětka (nedostatečná) nebyla do vzorku zahrnuta.

\section{ACKNOWLEDGEMENTS}

The study was supported by the Czech Science Foundation, project No. P407/16-17749S “Factors influencing map skills development in Czech schools". 